Annals of Plant and Soil Research 23(3): 297-303 (2021)

https://doi.org/10.47815/apsr.2021.10073

\title{
Rising levels of soil acidity in Meghalaya: Evidences and Imperatives
}

\author{
MANOJ KUMAR ${ }^{1,2 *}$, M.H. KHAN ${ }^{1,3}$ AND B.C. VERMA ${ }^{1,4}$ \\ ${ }^{1}$ ICAR Research Complex for NEH Region, Umiam - 793 103, Meghalaya, India \\ Received: April, 2021: Revised accepted: May, 2021
}

\begin{abstract}
In order to examine the current status of soil acidity in Meghalaya, representative soil samples $(n=497)$ were collected (during 2015-2016) from across the state and analyzed for soil acidity and associated parameters. Averaged across the samples, $\mathrm{pH}$ of the soils was found to be very strongly acidic (4.94). Nearly $20 \%$ of the soils had $\mathrm{pH}$ below $4.50,59 \%$ below pH 5.0 and $80 \%$ below pH 5.50 . Only $3.4 \%$ of the samples recorded $\mathrm{pH}$ more than 6.0. East Khasi Hills District had the maximum percentage (95.1\%) of strongly acidic soils $(\mathrm{pH} \leq 5.50)$ while Garo Hills had the least $(50.2 \%)$. All other districts recorded more than $85 \%$ of the strongly acidic soils. Average exchangeable acidity, exchangeable Al and effective CEC were found to be 1.60 , 1.27 and 3.86 meq/100g soil, respectively. Mean base saturation was recorded below $60 \%$. Aluminium saturation (percentage of effective CEC being occupied by exch. Al) ranged from 1.5 to $79.7 \%$ with its mean value being as high as 33\%. Principal component analysis provided three PCs with Eigen values $>1$ and together they explained $83.2 \%$ of the variance in total dataset. The soil acidity in Meghalaya is on rise, with $80.2 \%$ of its soils being strongly acidic $(\mathrm{pH} \leq 5.50)$ in contrast to the previous reports of $53 \%$ soils being strongly acidic. This calls for widespread adoption of soil acidity ameliorative measures in agriculture of Meghalaya, Northeast India.
\end{abstract}

Keywords: Exchangeable Al, base saturation, lime requirement, Al toxicity, $\mathrm{P}$ deficiency

\section{INTRODUCTION}

Acid soils occupy more than $30 \%$ of the world's ice-free land and nearly $50 \%$ of the potentially arable land. In India, nearly 25 million hectares $(\mathrm{m}$ ha) of land is having $\mathrm{pH}$ below 5.5 and another $23 \mathrm{~m}$ ha in the $\mathrm{pH}$ range of 5.6-6.5, which accounts approximately one-third of cultivated land in the country. Majority of them $(54 \%)$ are concentrated in North Eastern Region (NER) of India where more than $95 \%$ area is affected by acidity, with around $65 \%$ of the area being under extreme forms of soil acidity $(\mathrm{pH}$ below 5.5) (Sharma and Singh, 2002). Crop productivity on such soils is mostly constrained by aluminium (Al), iron (Fe) and manganese $(\mathrm{Mn})$ toxicity, and phosphorus $(\mathrm{P})$, calcium $(\mathrm{Ca})$ and magnesium (Mg) deficiency. This type of soil has mostly low base saturation, cation exchange capacity (CEC), impaired biological activity and other acidity-induced soil fertility and plant nutritional problems (Kumar, 2011 \& 2015; Kumar et al., 2016). Owing largely to these acidity-induced constraints, despite having $~ 6 \%$ of the total geographical area and $\sim 13 \%$ of the total rainfall of the country, the NER contributes only $1.5 \%$ to the national food grain production (Singh and Satapathy, 2007). Management of soil acidity therefore warrants top priority for enhancing crop productivity and ensuring food security in the region.

For effective management of soil acidity, knowledge of its extent and distribution in an area is important. Meghalaya is a hilly state in north-eastern India where, as per existing report by National Bureau of Soil Survey and Land Use Planning (NBSS\&LUP), as cited by Sharma and Sarkar (2005) and Sharma et al. (2006), 53\% of the geographical area is below $\mathrm{pH} 5.5$ and another $47 \%$ between $\mathrm{pH} 5.5$ to 6.5 , making soil acidity an omnipresent feature in the state. Thus, although entire soils of Meghalaya are acidic, the debilitating effect of soil acidity on crop growth is more pronounced below pH 5.5 (i.e. on $53 \%$ of soils in Meghalaya) where severity of Al toxicity and $\mathrm{P}$ deficiency is considered to be very high. Soil $\mathrm{pH}$ is a dynamic property which may change with time depending on rainfall and soil/nutrient management practices, among other factors. High rainfall increases soil acidity consequent to leaching of basic cations from soil profile. Application of acid-producing fertilisers (ammonium-based fertilisers) for long-term may also contribute to soil acidity. Considering the traditionally low use of fertilisers in Meghalaya, the excessive rainfall (2400 $\mathrm{mm}$ average annual

*Corresponding author email: mkumar_iari@yahoo.co.in_ ${ }^{\star} I C A R$ Research Complex for Eastern Region, RCM, Darbhanga - Bihar, India, ${ }^{3}$ ICAR-NRC on Mithun, Medziphema - Nagaland, Indi, ${ }^{4}$ CRURRS, ICAR-NRRI, Hazaribagh Jharkhand, India 
rainfall) is perceived to be the prime factor responsible for high levels of soil acidity in the state. In view of the excessively high rainfall in Meghalaya (which is credited to have some of the wettest places on earth - Mawsynram and Cherrapunji), the levels of soil acidity could be expected to be rising with time, necessitating thereby the periodic appraisal of soil acidity in the state.

Although important, measurement of soil $\mathrm{pH}$ alone is not a true representation of soil acidity. The acidity-induced impact on soil fertility and plant growth is mediated largely through its effect on nutrient availability/toxicity in crop rhizosphere, which in turn is governed by various acidity components (total, exchangeable and non-exchangeable acidity, exchangeable Al and $\mathrm{H}$ ) and associated soil parameters (such as exchangeable $\mathrm{Ca}$ and $\mathrm{Mg}$, cation exchange capacity, base saturation, acid and Al saturation levels in soil etc.). Understanding of these acidity components and associated soil attributes are therefore crucial to better appreciate the effect of soil acidity on plant growth and to formulate strategies for effective soil acidity management. For example, soil pH alone is of little use while estimating lime requirement of acidic soils; exchangeable $\mathrm{Al}$ rather gives a better indication of the same. Also, while $P$ adsorption in acidic soils is usually considered to be higher in soil with low $\mathrm{pH}$ and vice-versa, many a times the opposite could be observed based on the interplay of the effects of exchangeable Al vis-àvis $\mathrm{Ca}$ and $\mathrm{Mg}$ levels (as observed frequently in recently limed soils). These instances further necessitate the wholesome understanding of the acidity components instead of soil pH alone. In this backdrop, based on the analysis of soil samples collected from across the state, we are reporting here the current extent and distribution (district-wise) of soil acidity and acidity components in soils of Meghalaya, hoping that the information will be useful for efficient management of soil acidity for crop production in the region.

\section{MATERIAL AND METHODS}

In order to examine the levels of soil acidity and acidity components in Meghalaya, a total of 497 soil samples $(0-20 \mathrm{~cm}$ depth) were collected (during 2015-16) from across the districts of Meghalaya, namely East Khasi Hills (81), Garo Hills (East, West and South Garo Hills) (126), Jaintia Hills (97), Ri-Bhoi (115) and West Khasi Hills (78). Soil samples were airdried and passed through $2.0 \mathrm{~mm}$ sieve for analysis of acidity and acidity parameters. Soil $\mathrm{pH}$ was measured in 1: 2.5 soil: water ratio. Total acidity $\left(\mathrm{H}^{+}+\mathrm{Al}^{3+}\right)$ was measured directly by the extraction with molar ammonium acetate solution at $\mathrm{pH} 7$, followed by titration. Exchangeable Al and acidity was determined by potassium chloride method (McLean, 1965; Page et al., 1982) and exchangeable $\mathrm{Ca}$ and $\mathrm{Mg}$ were determined through versene titration (Baruah and Barthakur, 1999). Effective CEC (ECEC) was calculated as the sum total of exchangeable cations ( $\mathrm{K}, \mathrm{Ca}, \mathrm{Mg}, \mathrm{Al}$ and $\mathrm{H})$. The difference between exchangeable acidity and exchangeable aluminum gave the estimation of exchangeable hydrogen $\left(\mathrm{H}^{+}\right)$content. Non exchangeable acidity was found as the difference between total acidity and exchangeable acidity. Percentage of the basic cations in $\mathrm{CEC}_{e}$ was taken as base saturation (BS) while that of exchange acidity was deemed as acid saturation (AS). Percentage of $\mathrm{CEC}_{\mathrm{e}}$ occupied by exchangeable $\mathrm{Al}$ was taken as Aluminum saturation (AIS). Data were subjected to the analyses of descriptive statistics where mean, median, standard deviation, range, minimum and maximum values were estimated using standard statistical procedures. Pearson's correlation coefficients were used to determine the strength of relationships among soil attributes. Principal component analysis was also undertaken to know the principal components (PC) with their Eigen values and proportion of variance (\%) explained, along with rotated factor loadings and communalities of soil acidity-related attributes.

\section{RESULTS AND DISCUSSION}

Analysis of the soil samples revealed wide variations in acidity and associated components across the soils of Meghalaya. Soil $\mathrm{pH}$ ranged from as low as 3.73 in West Khasi Hills to near neutral (6.97) in Garo Hills, with a difference of over $3.2 \mathrm{pH}$ unit between maximum and minimum values (Table 1 ). 
Table 1: Descriptive statistics of the soil $\mathrm{pH}$ in Meghalaya

\begin{tabular}{c|c|c|c|c|c|}
\hline District & No. of samples & Minimum & Maximum & Mean & Standard Deviation \\
\hline East Khasi Hills & 81 & 3.94 & 5.59 & 4.75 & 0.37 \\
Garo Hills & 126 & 4.50 & 6.97 & 5.40 & 0.62 \\
Jaintia Hills & 97 & 4.45 & 5.57 & 5.09 & 0.32 \\
Ri-Bhoi & 115 & 3.75 & 5.82 & 4.74 & 0.47 \\
West Khasi Hills & 78 & 3.73 & 5.76 & 4.74 & 0.44 \\
Total (Meghalaya) & 497 & 3.73 & 6.97 & 4.94 & 0.54 \\
\hline
\end{tabular}

*includes samples from all the three districts of Garo Hills i.e. East, West and South Garo Hills

Mean $\mathrm{pH}$ of the soils in Meghalaya was found to be strongly acidic (4.94). Nearly $20 \%$ of the soils had $\mathrm{pH}$ below $4.50,59 \%$ below $\mathrm{pH}$ 5.0 and $80 \%$ below pH 5.50 . Only $20 \%$ of the samples recorded $\mathrm{pH}$ more than 5.50 with merely $3.4 \%$ of the soils having $\mathrm{pH}$ more than
6.0 (Table 2). East Khasi Hills District had the maximum percentage $(95.1 \%)$ of strongly acidic soils $(\mathrm{pH} \leq 5.50)$ while Garo Hills had the least percentage $(50.2 \%)$ of such soils. All other districts recorded more than $85 \%$ of the strongly acidic soils (Fig.1).

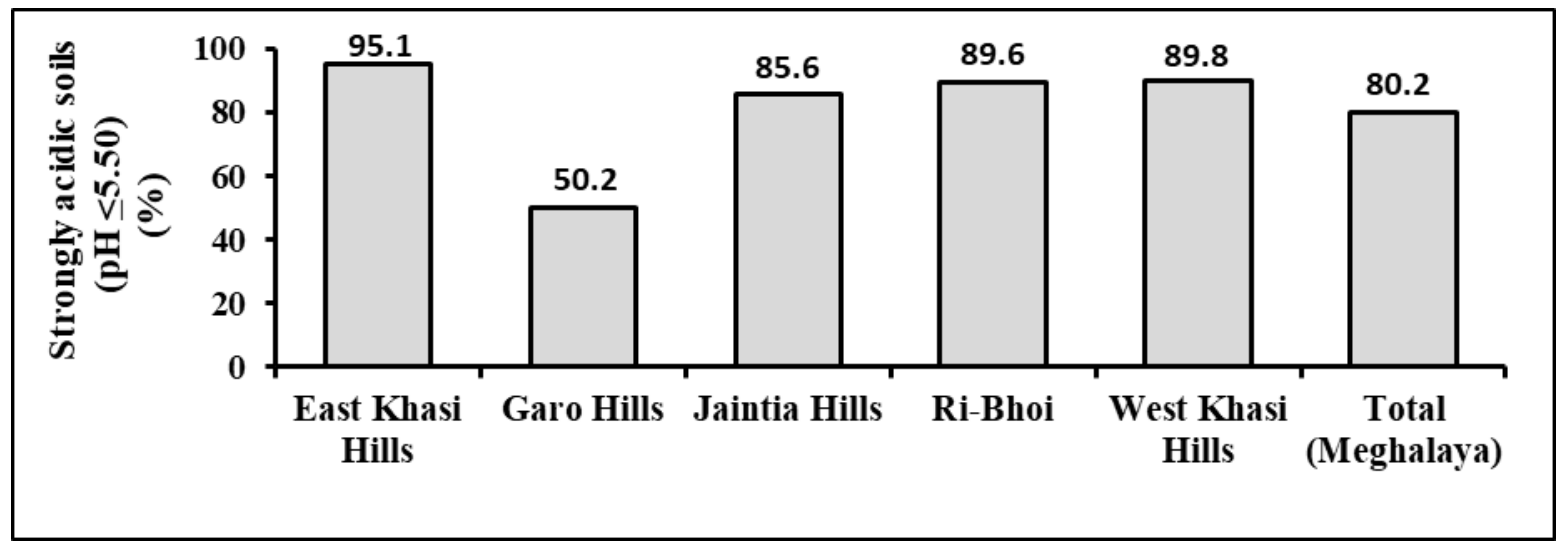

Figure 1: Extent (\%) and distribution of strongly acidic soils $(\mathrm{pH} \leq 5.50)$ in Meghalaya (Garo Hills represent all the three districts of Garo Hills: East, West and South Garo Hills)

Table 2: Extent and distribution of soil acidity in Meghalaya

\begin{tabular}{c|cccccc|}
\hline \multirow{2}{*}{ District } & \multicolumn{5}{|c|}{ Percentage of samples in different acidity classes } \\
\cline { 2 - 6 } & $\mathrm{pH} \leq 4.50$ & $\mathrm{pH} \mathrm{4.51-5.00}$ & $\mathrm{pH} \mathrm{5.01-5.50}$ & $\mathrm{pH} 5.51-6.00$ & $\mathrm{pH} \mathrm{pH}>6.00$ \\
\hline East Khasi Hills & 34.6 & 48.1 & 12.3 & 4.9 & - \\
Garo Hills* & 4.8 & 22.7 & 22.7 & 32.6 & 12.8 \\
Jaintia Hills & 6.2 & 33.0 & 46.4 & 14.4 & - \\
Ri-Bhoi & 29.6 & 47.8 & 12.2 & 10.4 & - \\
West Khasi Hills & 29.5 & 50.0 & 10.3 & 10.3 & - \\
Total (Meghalaya) & 19.7 & 39.0 & 21.5 & 16.3 & 3.4 \\
\hline
\end{tabular}

*includes samples from all the three districts of Garo Hills i.e. East, West and South Garo Hills

District-wise details of the acidity and related parameters and overall summary for the state are shown in Table 3. Mean total acidity, exchangeable acidity and exchangeable $\mathrm{Al}$ in the soils of Meghalaya were found to be $3.41,1.60$ and $1.27 \mathrm{meq} / 100 \mathrm{~g}$ soil, respectively. While effective CEC ranged from 1.84 to 17.2 meq $/ 100 \mathrm{~g}$ soil with a mean value of just 3.86 . Mean base saturation was recorded below $60 \%$ while acid saturation was found above $40 \%$. Percentage of effective CEC being occupied by exch. Al (Aluminium saturation) ranged from 1.5 to $79.7 \%$ with a mean value being as high as $33 \%$. 
Table 3: Soil acidity and related attributes (district-wise) in soils of Meghalaya

\begin{tabular}{|c|c|c|c|c|c|c|c|c|c|c|c|c|c|}
\hline & $\mathrm{pH}$ & $\begin{array}{l}\text { Total } \\
\text { acidity }\end{array}$ & \begin{tabular}{|l|} 
Exch. \\
acidity
\end{tabular} & $\begin{array}{c}\text { Exch. } \\
\mathrm{Al}\end{array}$ & $\begin{array}{c}\text { Exch. } \\
\mathrm{H}\end{array}$ & $\begin{array}{c}\text { Non-Exch. } \\
\text { acidity }\end{array}$ & $\begin{array}{c}\text { Exch. } \\
\mathrm{Ca}\end{array}$ & \begin{tabular}{|c|} 
Exch. \\
$\mathrm{Mg}$
\end{tabular} & $\begin{array}{c}\text { Exch. } \\
\mathrm{K}\end{array}$ & $\mathrm{CEC}_{\mathrm{e}}$ & $\begin{array}{l}\text { BS } \\
(\%)\end{array}$ & $\begin{array}{l}\text { AS } \\
(\%)\end{array}$ & $\begin{array}{l}\text { AIS } \\
(\%)\end{array}$ \\
\hline \multicolumn{14}{|c|}{ (meq/100g soil) } \\
\hline \multicolumn{14}{|c|}{ Eeast Khasi Hills $(n=81)$} \\
\hline Minimum & 3.94 & 1.85 & 0.63 & 0.25 & 0.13 & 1.13 & 0.40 & 0.10 & 0.09 & 1.84 & 16.9 & 24.2 & 10.8 \\
\hline Maximum & 5.46 & 6.45 & 3.75 & 3.38 & 0.63 & 3.63 & 2.60 & 1.10 & 0.40 & 4.78 & 75.8 & 83.1 & 74.8 \\
\hline Mean & 4.70 & 4.11 & 1.89 & 1.59 & 0.30 & 2.22 & 0.90 & 0.45 & 0.19 & 3.43 & 44.9 & 55.1 & 46.4 \\
\hline Std. Dev. & 0.38 & 1.45 & 0.81 & 0.83 & 0.17 & 0.78 & 0.57 & 0.29 & 0.10 & 0.99 & 18.0 & 18.0 & 19.2 \\
\hline \multicolumn{14}{|c|}{ West Khasi Hills $(n=78)$} \\
\hline Minimum & 4.45 & 1.98 & 0.63 & 0.25 & 0.02 & 0.93 & 0.30 & 0.10 & 0.01 & 2.38 & 17.8 & 16.9 & 9.5 \\
\hline Maximum & 5.76 & 4.08 & 2.13 & 2.00 & 0.75 & 2.45 & 1.70 & 2.50 & 0.44 & 5.19 & 83.2 & 82.2 & 71.9 \\
\hline Mean & 4.78 & 3.18 & 1.49 & 1.19 & 0.30 & 1.70 & 0.66 & 0.59 & 0.12 & 2.86 & 47.9 & 52.1 & 41.6 \\
\hline Std. Dev. & 0.41 & 0.58 & 0.47 & 0.54 & 0.20 & 0.49 & 35 & 0.62 & 0.12 & .70 & 19.5 & 19.5 & 20.8 \\
\hline \multicolumn{14}{|c|}{ Ri-Bhoi $(n=115)$} \\
\hline Minimum & 3.73 & 2.25 & 0.62 & 0.50 & 0.02 & 0.00 & 0.30 & 0.00 & 0.07 & 2.10 & 19.4 & 15.4 & 12.4 \\
\hline Maximum & 5.30 & 4.70 & 2.40 & 2.38 & 0.25 & 3.08 & 2.00 & 1.10 & 0.32 & 4.00 & 84.6 & 80.6 & 79.7 \\
\hline Mean & 4.52 & 3.82 & 1.78 & 1.63 & 0.15 & 2.04 & 0.55 & 0.37 & 0.15 & 2.85 & 37.6 & 62.4 & 57.2 \\
\hline Std. Dev. & 0.38 & 0.71 & 0.48 & 0.50 & 0.10 & 0.71 & 0.42 & 0.31 & 0.07 & 0.44 & 17.5 & 17.5 & 17.6 \\
\hline \multicolumn{14}{|c|}{ Jaintia Hills $(n=97)$} \\
\hline Minimum & 4.48 & 1.65 & 1.12 & 0.50 & 0.12 & 0.48 & 0.40 & 0.00 & 0.09 & 2.10 & 16.3 & 37.1 & 14.8 \\
\hline Maximum & 5.52 & 5.45 & 2.88 & 2.25 & 1.75 & 3.23 & 1.10 & 1.00 & 0.52 & 5.10 & 62.9 & 83.7 & 75.3 \\
\hline Mean & 5.10 & 3.72 & 1.94 & 1.23 & 0.71 & 1.78 & 0.73 & 0.27 & 0.20 & 3.13 & 38.0 & 62.0 & 39.3 \\
\hline Std. Dev. & 0.28 & 1.21 & 0.55 & 0.54 & 0.49 & 1.00 & 0.18 & 0.28 & 0.12 & 0.74 & 11.5 & 11.5 & 16.6 \\
\hline \multicolumn{14}{|c|}{ Garo Hills $(n=126)$} \\
\hline Minimum & 4.50 & 0.95 & 0.38 & 0.25 & 0.00 & 0.08 & 0.60 & 0.00 & 0.03 & 2.50 & 34.7 & 2.2 & 1.5 \\
\hline Maximum & 6.97 & 4.73 & 1.88 & 1.75 & 0.63 & 3.23 & 14.90 & 3.70 & 1.20 & 17.20 & 97.8 & 65.3 & 61.0 \\
\hline Mean & 5.40 & 2.49 & 1.06 & 0.86 & 0.20 & 1.44 & 3.72 & 1.13 & 0.34 & 6.24 & 83.0 & 17.0 & 13.8 \\
\hline Std. Dev. & 0.64 & 0.94 & 0.43 & 0.45 & 0.17 & 0.90 & 3.97 & 1.00 & 0.31 & 4.49 & 21.4 & 21.4 & 19.7 \\
\hline \multicolumn{14}{|c|}{ Meghalaya $(n=497)$} \\
\hline Minimum & 3.73 & 0.95 & 0.38 & 0.25 & 0.00 & 0.00 & 0.30 & 0.00 & 0.01 & 1.84 & 16.3 & 2.2 & 1.5 \\
\hline Maximum & 6.97 & 6.45 & 3.75 & 3.38 & 1.75 & 3.63 & 14.90 & 3.70 & 1.20 & 17.20 & 97.8 & 83.7 & 79.7 \\
\hline Mean & 4.94 & 3.41 & 1.60 & 1.27 & 0.33 & 1.82 & 1.46 & 0.59 & 0.21 & 3.86 & 58.5 & 41.5 & 32.9 \\
\hline Std. Dev. & 0.54 & 1.19 & 0.66 & 0.65 & 0.33 & 0.85 & 2.38 & 0.68 & 0.19 & 2.70 & 22.3 & 22.3 & 21.9 \\
\hline
\end{tabular}

BS: base saturation; AS: acid saturation; AIS: aluminium saturation; CEC $C_{e}$ : effective CEC; Std. Dev.: standard deviation

Soil pH was most strongly correlated with the quantity of exch. Al and percentage of the effective CEC being occupied by exch. Al i.e. Al saturation, while effective CEC was most strongly correlated with exch. Ca followed by exch. Mg (Table 4). In the entire correlation matrix, association of effective CEC with exch. Ca was the strongest one $(r=0.97)$. PCA was performed on measured soil attributes which provided three PC with Eigen values $>1$ and together they explained $83.2 \%$ of the variance in total dataset (Table 5). A total of $57.3 \%$ of the variance was explained by PC-1 itself which has effective CEC as the highest weighted variable (0.915). 
Table 4: Correlation matrix for soil acidity and related attributes in the soils of Meghalaya

\begin{tabular}{|c|c|c|c|c|c|c|c|c|c|c|c|c|c|}
\hline & $\mathrm{pH}$ & $\begin{array}{l}\text { Total } \\
\text { acidity }\end{array}$ & $\begin{array}{l}\text { Exch. } \\
\text { acidity }\end{array}$ & $\begin{array}{l}\text { Exch. } \\
\text { Al }\end{array}$ & $\begin{array}{l}\text { Exch. } \\
\mathrm{H}\end{array}$ & \begin{tabular}{|l} 
Non- \\
Ex. \\
acidity
\end{tabular} & $\begin{array}{l}\text { Exch. } \\
\mathrm{Ca}\end{array}$ & $\begin{array}{l}\text { Exch. } \\
\text { Mg }\end{array}$ & $\begin{array}{l}\text { Exch. } \\
\mathrm{K}\end{array}$ & $\mathrm{CEC}_{\mathrm{e}}$ & BS & AS & AIS \\
\hline $\mathrm{pH}$ & 1 & & & & & & & & & & & & \\
\hline Total acidity & $-0.70^{* *}$ & & & & & & & & & & & & \\
\hline Exch. acidity & $-0.67^{\star *}$ & $0.72^{* *}$ & 1 & & & & & & & & & & \\
\hline Exch. Al & $-0.78^{* *}$ & $0.77^{\star *}$ & $0.88^{* *}$ & 1 & & & & & & & & & \\
\hline Exch. $\mathrm{H}$ & $0.21^{* *}$ & ns & $0.27^{\star *}$ & $-0.23^{* *}$ & 1 & & & & & & & & \\
\hline Non-Ex. acidity & $-0.46^{* *}$ & $0.84^{* *}$ & $0.24^{* *}$ & $0.41^{* *}$ & $-0.34^{* *}$ & 1 & & & & & & & \\
\hline Exch. Ca & $0.65^{* *}$ & $-0.34^{* *}$ & $-0.52^{* *}$ & $-0.46^{\star *}$ & $-0.13^{*}$ & ns & 1 & & & & & & \\
\hline Exch. Mg & $0.53^{* *}$ & $-0.27^{* *}$ & $-0.53^{* *}$ & $-0.48^{* *}$ & ns & ns & $0.72^{* \star}$ & 1 & & & & & \\
\hline Exch. K & $0.46^{* *}$ & $-0.22^{\star *}$ & $-0.36^{* *}$ & $-0.37^{\star *}$ & ns & ns & $0.43^{* *}$ & $0.38^{* *}$ & 1 & & & & \\
\hline $\mathrm{CEC}_{\mathrm{e}}$ & $0.58^{* *}$ & $-0.21^{* *}$ & $-0.38^{* *}$ & $-0.34^{* *}$ & ns & ns & $0.97^{\star \star}$ & $0.79^{\star *}$ & $0.46^{\star *}$ & 1 & & & \\
\hline BS & $0.73^{* *}$ & $-0.52^{\star *}$ & $-0.83^{\star \star}$ & $-0.78^{* \star}$ & $-0.12^{*}$ & ns & $0.70^{\star \star}$ & $0.80^{\star \star}$ & $0.54^{\star *}$ & $0.66^{\star *}$ & 1 & & \\
\hline AS & $-0.73^{\star *}$ & $0.52^{* *}$ & $0.83^{* *}$ & $0.78^{* *}$ & $0.12^{*}$ & ns & $-0.70^{* *}$ & $-0.80^{* *}$ & $-0.54^{* *}$ & $-0.66^{* *}$ & $-1.0^{\star *}$ & 1 & \\
\hline AIS & $-0.80^{* *}$ & $0.58^{\star *}$ & $0.74^{* *}$ & $0.89 * *$ & $-0.28^{\star *}$ & $0.23^{\star *}$ & $-0.60^{* *}$ & $-0.68^{* *}$ & $-0.51^{* *}$ & $-0.56^{\star *}$ & $-0.91^{* *}$ & * 0.91 ** & ${ }^{*} 1$ \\
\hline
\end{tabular}

Results of the present study had quite a few critical revelations regarding rising levels of soil acidity in Meghalaya which has relevance to the acid soil management for enhancing crop productivity and food security in the region. As per the previous reports, as cited by Sharma and Sarkar (2005), and Sharma et al. (2006), 53\% of the soils in Meghalaya were strongly acidic $(\mathrm{pH} \leq$ 5.50 ), while our present study shows that $80.2 \%$ of the soils in the state are strongly acidic which suggests that soil acidity in Meghalaya is intensifying with time. This can be attributed to the fact that while acidity causing factors like rainfall and base feeding by growing crops are constantly in operation, acidity ameliorative measures like liming (and other supplements with liming values) are not being practiced on large scale in the state. Acidic nature of the parent materials (granitic parent rock) might also be contributing to the increases in soil acidity in the region. Rise in soil acidity may also be caused by the rising levels of atmospheric $\mathrm{CO}_{2}$. A decade back, Kumar (2011) had reasoned that soil acidity, the biggest impediment to crop productivity in North-eastern region, may further intensify under the rising atmospheric $\mathrm{CO}_{2}$ concentrations. This possibility stems from the frequent experimental observation of increased $\mathrm{CO}_{2}$ production in soil due to enhanced soil respiration under elevated $\mathrm{CO}_{2}$ conditions (Gill et al., 2002). Elevated $\mathrm{CO}_{2}$ stimulates photosynthesis leading to higher accumulations of photosynthates in plants. Since up to one third of the photosynthates find entry into soil as rhizo-deposites, there is higher accumulation of carbon-rich rhizo-deposites in soil under elevated $\mathrm{CO}_{2}$ which serves as food source for soil microbes, leading to improved soil respiration and more $\mathrm{CO}_{2}$ production in soil. It leads to more carbonic acid formation in soil water, which upon leaching, removes base cations from soil, thereby causing soil acidification (Oh and Richter, 2004). Modelling studies by Oh and Richter (2004) suggested that a doubling of atmospheric $\mathrm{CO}_{2}$ concentration may increase acid inputs from $\mathrm{H}_{2} \mathrm{CO}_{3}$ leaching by up to $50 \%$. They also asserted that increases in atmospheric $\mathrm{CO}_{2}$ since the interglacial era might have caused gradual acidification of soils globally, and will continue to do so in the high$\mathrm{CO}_{2}$ atmosphere of the future. 
Table 5: Results of principal component analysis showing principal components (PC) with their Eigen values and proportion of variance (\%) explained, along with rotated factor loadings and communalities of soil acidity-related attributes

\begin{tabular}{l|c|c|c|c|}
\hline Soil parameters & PC-2 & PC-1 & PC-3 & Communalities \\
\hline pH & -0.641 & 0.618 & 0.179 & 0.825 \\
Total acidity & 0.953 & -0.147 & -0.018 & 0.929 \\
Exch. acidity & 0.728 & -0.470 & 0.447 & 0.951 \\
Exch. Al & 0.811 & -0.474 & -0.019 & 0.883 \\
Exch. H & -0.149 & -0.002 & 0.939 & 0.903 \\
Non-Exch. acidity & 0.772 & 0.158 & -0.371 & 0.758 \\
Exch. Ca & -0.131 & 0.869 & -0.069 & 0.777 \\
Exch. Mg & -0.131 & 0.855 & -0.162 & 0.774 \\
Exch. K & -0.126 & 0.622 & 0.095 & 0.411 \\
CEC e & 0.020 & 0.915 & 0.012 & 0.837 \\
Base Saturation (\%) & -0.470 & 0.811 & -0.245 & 0.940 \\
Acid Saturation (\%) & 0.470 & -0.811 & 0.245 & 0.940 \\
Al Saturation (\%) & 0.569 & -0.740 & -0.118 & 0.886 \\
Eigen values & 2.18 & 7.44 & 1.19 & \\
Variance explained (\%) & 16.8 & 57.3 & 9.1 & \\
Cumulative variance explained (\%) & 74.1 & 57.3 & 83.2 & \\
\hline
\end{tabular}

Extraction Method: Principal Component Analysis. Rotation Method: Varimax with Kaiser Normalization.

The soils were mostly depleted in basic cations, reflecting in very low effective CEC and base saturation in the soils. Conversely, acid saturation and more importantly $\mathrm{Al}$ saturation of the soils (\% of the ECEC occupied by exch. Al) were very high, raising concerns for Aluminium toxicity to the plants growing thereon. The strongest correlation of effective CEC with exchangeable $\mathrm{Ca}$ underlines the utility of liming and $\mathrm{Ca}$ containing amendments to improve the ECEC and thus fertility of these soils (Kumar et al., 2012 a \& b). Ratio of exch. Ca to Mg should be ideally near 5.0 for a soil with good fertility. However, this ratio was also very low (2.47) across the soils of Meghalaya; Ca containing amendments are therefore required to improve this ratio. Importance of effective CEC and exch. $\mathrm{Al}$ as the determinants of soil fertility in such soils was also highlighted by the results of principal components analysis.

Based on the results of our study, it may be conducted that the soil acidity in Meghalaya is intensifying with time as we found over $80 \%$ of the soils to be strongly acidic $(\mathrm{pH} \leq 5.50)$ in contrast to the previously known level (53\%). Base saturation, an important fertility parameter, was found well below $50 \%$ in most of the soils, except for Garo Hills' soils. Conversely, Al saturation was frequently found in excess of $50 \%$ in majority of the soils. High levels of soil acidity coupled with low base saturation and high abundance of exchangeable $\mathrm{Al}$ pose serious management challenges to the agriculture of the state. Liming, an ameliorative practice usually recommended for acid soils, needs to be taken more seriously and should be promoted on wider scale to make the soils better suited for crop production.

\section{ACKNOWLEDGEMENT}

Authors are thankful to the Director, ICAR RC for NEH Region, Umiam. 


\section{REFERENCES}

Baruah, T.C. and Barthakur, H.P. (1999) A text book of soil analysis. Vikas: New Delhi.

Gill, R.A., Polley, H.W., Johnson, H.B., Anderson, L.J., Maherali, $H$. and Jackson, R.B. (2002) Nonlinear grassland responses to past and future atmospheric $\mathrm{CO}_{2}$. Nature 16: 417(6886): 279-82.

Kumar, M. (2011) North East India: soil and water management imperatives for food security in a changing climate. Current Science 101: 1119.

Kumar, M. (2015) Phosphate requirement of acidic soils in Northeast India: A reappraisal based on phosphate sorption isotherms. National Academy Science Letters 38: 383-386.

Kumar, M., Hazarika, S., Choudhury, B.U., Ramesh, T., Verma, B.C. and Bordoloi, L.J. (2012a) Liming and integrated nutrient management for enhancing maize productivity on acidic soils of northeast India. Indian Journal of Hill Farming 25(1): 36-38.

Kumar, M., Jha, A.K., Hazarika, S., Verma, B.C., Choudhury, B.U., Ramesh, T., Moirangthem, P., Kumar, R., Brajendra, Rajkhowa, D.J., Kumar, A. and Devi, M.H. (2016) Micronutrients (B, Zn, Mo) for improving crop production on acidic soils of Northeast India. National Academy Science Letters 39(2): 85-89.

Kumar, M., Khan, M.H., Singh, P., Ngachan, S.V., Rajkhowa, D.J., Kumar, A. and Devi, M.H. (2012b) Variable lime requirement based on differences in organic matter content of iso-acidic soils. Indian Journal of Hill Farming 25(1): 2630.

McLean, E.O. (1965) Aluminum. In: Black, C.A. (Ed.) Methods of soil analysis: Part 2. Chemical methods. Madison: ASA, 1965. p.978-998.

Oh N-H. and Richter, D.D. (2004) Soil acidification induced by elevated atmospheric $\mathrm{CO}_{2}$. Global Change Biology 10: 1936-1946.

Page, A.L., Miller, R.H. and Keeney, D.R. (1982) Methods of soil analysis (part 2). American Society of Agronomy and Soil Science Society of America. Wisconsin, USA: Madison.

Sharma, P.D. and Sarkar, A.K. (2005) Managing acid soils for enhancing productivity. New Delhi: NRM Division, ICAR.

Sharma, P.D., Baruah, T.C., Maji, A.K. and Patiram (2006) Management of acid soils in NEH Region, Natural Resource Management Division (ICAR), Krishi Anusandhan Bhawan-II, Pusa Campus, New Delhi. Technical Bulletin, pp 14.

Sharma, U.C. and Singh, R.P. (2002) Acid soils of India: their distribution, management and future strategies for higher productivity. Fertilizer News 47: 45-52.

Singh, R.K. and Satapathy, K.K. (2007) Scope and adoption of plasticulture technologies for enhancing production in north east hill region. Himalayan Ecology 15:14-21. 